\title{
Physiological Quality and Seed Production of Corn and Fabaceae in Monoculture and Intercropping
}

\author{
Anna Christina Sanazário de Oliveira1, Fábio Cunha Coelho², Henrique Duarte Vieira ${ }^{3}$, \\ Jocarla Ambrosim Crevelari' ${ }^{3}$, Áurea Izabel Aguiar Fonseca e Souza4, Tiago Massi Ferraz, \\ Antônia Alice Costa Rodrigues ${ }^{1}$
}

\footnotetext{
${ }^{1}$ Programa de Pós-Graduação em Agroecologia, Centro de Ciências Agrárias, Universidade Estadual do Maranhão, São Luís, Brasil ${ }^{2}$ Laboratório de Fitotecnia, Campos dos Goytacazes, Universidade do Norte Fluminense Darcy Ribeiro, Campos, Brasil ${ }^{3}$ Laboratório de Melhoramento Genético Vegetal, Campos dos Goytacazes, Universidade do Norte Fluminense Darcy Ribeiro, Campos, Brasil

${ }^{4}$ Universidade Federal Rural da Amazônia, Belém, Brasil

Email: annasanazario@gmail.com, fabiocuncoelho@gmail.com, vieira.henrique101@gmail.com, jcrevelari@yahoo.com.br, aurea.aguiar@yahoo.com.br,ferraztm@gmail.com, aacrodrigues@outlook.com
}

How to cite this paper: de Oliveira, A.C.S., Coelho, F.C., Vieira, H.D., Crevelari, J.A., e Souza, Á.I.A.F., Ferraz, T.M. and Rodrigues, A.A.C. (2017) Physiological Quality and Seed Production of Corn and Fabaceae in Monoculture and Intercropping. American Journal of Plant Sciences, 8, 2597-2607. https://doi.org/10.4236/ajps.2017.811175

Received: July 10, 2017

Accepted: October 9, 2017

Published: October 12, 2017

Copyright $(0) 2017$ by authors and Scientific Research Publishing Inc. This work is licensed under the Creative Commons Attribution International License (CC BY 4.0).

http://creativecommons.org/licenses/by/4.0/

\begin{abstract}
The aim of this study was to evaluate the physiological quality and seed production of Fabaceae and corn in monoculture and intercropping in areas cropped under different management. The following treatments were evaluated: corn + NPK + weed control; corn + weed control; corn + NPK; corn + crotalaria; corn + jack bean. Intercropping raised the average number of corn ears of corn and the seed IVG Weed control positively influenced the final stand and average number of ears. NPK fertilization on corn sowing positively influenced the seed electrical conductivity. The yield of corn plants intercropped with crotalaria and jack bean was statistically similar. However, their absolute values should be considered for economic purposes. Corn seeds derived from intercropping with crotalaria were more effective compared with intercropping with jack bean. Crotalaria and jack bean seeds when intercropped with corn have high production, germination and vigor (IVG and emergence).
\end{abstract}

\section{Keywords}

Zea mays, Green Manure, No-Till System, Vigor, Germination, Green Manure

\section{Introduction}

Intercropped corn and Fabaceae seed production is an important alternative for 
family farmers in the economic sustainability of their production units. Fabaceae seeds have a high market price, which provides this type of producer with the possibility to produce them instead of buying. However, many of the farmers who own smaller areas are reluctant to produce Fabaceae seeds in monoculture, mainly because it decreases the food production area while intercropping with corn is not always adopted because of the lack of information about its viability. Thus, intercropped areas for quality Fabaceae seed production are not seen in the field, mainly due to the fear of causing a drop in corn yields and economic losses.

This type of management has advantages, such as recovery of low-fertility soils, increased yield and a reduced machinery use, which, in family farming, is an extremely important factor, since there is a considerable reduction in production costs and increase in production. The use of green manures improves the physical and chemical characteristics of the soil and yield in various crops. The contribution to soil fertility by nutrient supply is one of the qualities expected of the use of green manure. Fabaceae contributes with nitrogen fixing, increasing and maintaining nitrogen in the soil [1] [2].

According to the Brazilian Enterprise for Agricultural Research [3], hybrids have high vigor and yield in the first generation (F1), so that hybrid seeds need to be purchased every year. If the harvested grains were seeded, depending on the type of the hybrid, there will be a $15 \%$ - $40 \%$ reduction in yield due to vigor loss and the great variation between plants. In spite of this reduction, many producers continue sowing the second-generation hybrid (F2). Therefore, research into the quality of these seeds is important.

The use of quality seeds provides crop formation without failure and with adequate plant population, as well as improved uniformity, easier harvesting, pest disease and lodging resistance (which also facilitates harvesting), and better soil and climate adaptation, resulting in higher yields [4].

Thus, the objective of the present study was to evaluate the physiological quality and the seed production of Fabaceae and corn in monoculture and intercropped areas cropped under different management.

\section{Material and Methods}

The experiment was conducted in the 2011/2012 spring/summer period, at the Research and Extension Support Unit ("Unidade de Apoio a Pesquisa e Extensão") of the [State University] Universidade Estadual do Norte Fluminense Darcy Ribeiro, in Campos dos Goytacazes/RJ, Brazil. The soil is a Haplic Cambisol, according to the Brazilian System of Soil Classification ("Sistema Brasileiro de Classificação do Solo") [5], a silt loam with $10 \%$ sand, $77.2 \%$ silt and $12.8 \%$ clay for the chemical characteristics of the $0 \mathrm{~cm}$ to $20 \mathrm{~cm}$ deep layer, analyzed according to Brazilian Agricultural Research Corporation [6] by the soil laboratory of the Federal Rural University of Rio de Janeiro ("Universidade Federal Rural do Rio de Janeiro") in Campos dos Goytacazes/RJ, when the experiment was installed (Table 1). 
Table 1. Values of chemical characteristics of the soil material during the equipment installation (2011), in Campo dos Goytacazes/RJ, and their classifications.

\begin{tabular}{|c|c|c|c|c|c|c|}
\hline $\mathrm{pH}$ & $\begin{array}{c}\mathrm{P}^{*} \\
\left(\mathrm{mg} \cdot \mathrm{dm}^{-3}\right)\end{array}$ & $\begin{array}{c}\mathrm{K}^{*} \\
\left(\mathrm{mg} \cdot \mathrm{dm}^{-3}\right)\end{array}$ & & $\begin{array}{c}\mathrm{Ca} \\
\left(\mathrm{cmol}_{c} \cdot \mathrm{m}^{-3}\right)\end{array}$ & $\begin{array}{c}\mathrm{Mg} \\
\left(\mathrm{cmol}_{\mathrm{c}} \cdot \mathrm{dm}^{-3}\right)\end{array}$ & $\begin{array}{c}\mathrm{Al} \\
\left(\mathrm{cmol}_{c} \cdot \mathrm{dm}^{-3}\right)\end{array}$ \\
\hline 5.9 & 4 & 69 & & 6.3 & 3.9 & 0.0 \\
\hline $\mathrm{H}+\mathrm{Al}\left(\mathrm{cmol}_{c} \cdot \mathrm{dm}^{-3}\right)$ & $\begin{array}{c}\mathrm{Na} \\
\left(\mathrm{cmol}_{c} \cdot \mathrm{dm}^{-3}\right)\end{array}$ & $\begin{array}{c}\text { S.B. } \\
\left(\mathrm{cmol}_{c} \cdot \mathrm{dm}^{-3}\right)\end{array}$ & & $\begin{array}{c}\mathrm{T} \\
\left(\mathrm{cmol}_{c} \cdot \mathrm{m}^{-3}\right)\end{array}$ & $\begin{array}{c}\mathrm{t} \\
\left(\mathrm{cmol}_{\mathrm{c}} \cdot \mathrm{dm}^{-3}\right)\end{array}$ & $\begin{array}{l}\text { MO } \\
(\mathrm{g} \cdot \mathrm{m})\end{array}$ \\
\hline 4.3 & 0.37 & 10.7 & & 15.0 & 10.7 & 30.5 \\
\hline C (\%) & M (\%) & V (\%) & $\begin{array}{c}\mathrm{Fe} \\
\left(\mathrm{mg} \cdot \mathrm{dm}^{-3}\right)\end{array}$ & $\begin{array}{c}\mathrm{Cu} \\
\left(\mathrm{mg} \cdot \mathrm{dm}^{-3}\right)\end{array}$ & $\begin{array}{c}\mathrm{Zn} \\
\left(\mathrm{mg} \cdot \mathrm{dm}^{-3}\right)\end{array}$ & $\begin{array}{c}\mathrm{Mn} \\
\left(\mathrm{mg} \cdot \mathrm{dm}^{-3}\right)\end{array}$ \\
\hline 1.77 & 0.0 & 71 & 61.2 & 3.1 & 4.0 & 22.2 \\
\hline
\end{tabular}

*North Carolina Extract.

The evaluated treatments were: corn in monoculture with NPK fertilizer at sowing and weed control (T1); corn in monoculture without NPK fertilizer at sowing and with weed control (T2); corn in monoculture with NPK fertilizer at sowing without weed control (T3); intercropped corn + crotalaria g (T4); intercropped corn + jack bean (T5).

The experiment was installed in a no-till system without using herbicide and the treatments were arranged on straw remaining from previous similar treatments. For this purpose, the dry plants from the previous cycle were cut and left in the experimental plot. Soon after, the drills were prepared using a furrower and a tractor to seed the treatments.

A randomized-block design was used with four replications.

Each experimental unit of the corn monoculture contained five $5 \mathrm{~m}$ rows with one-meter spacing. The experimental unit for each intercrop consisted of five rows of corn interspersed with four $5 \mathrm{~m}$ long rows of Fabaceae, spaced at one meter, with a useful area of three corn rows, discarding fifty centimeters from the ends.

The corn cultivar used was the interpopulation hybrid, UENF 506/11.

The soil was also analyzed to determine fertilization, recommended for the soils of the State of Rio de Janeiro [7]. The NPK doses applied were 80-80-20 $\mathrm{kg} \cdot \mathrm{ha}^{-1}$, using as sources ammonium (sulphate) sulfate, single superphosphate and potassium chloride, respectively. Single superphosphate and potassium chloride were applied in their totality with $2 / 3$ of the ammonium sulfate dose, immediately before sowing. The remaining $\mathrm{N}$ was applied in topdressing. This fertilization was applied only to the corn monoculture in $\mathrm{T} 1$ and $\mathrm{T} 3$ treatments, in the two crop cycles.

Nitrogen topdressing was applied 17 days after emergence in T1 and T3 treatments. At this time, the corn plants presented six to eight leaves. Since the corn plants were very small in the other treatments, the topdressing, with the same dosage as the $\mathrm{T} 1$ and $\mathrm{T} 3$ treatments, was applied to these treatments at 29 days after emergence.

Ten corn seeds were sown per meter, while for crotalaria fifteen seeds were 
sown per meter. For jack beans, four seeds were sown per meter. Corn plants were thinned when they reached six to eight leaves, leaving a population of 50,000 plants per hectare. Inoculation was conducted using Bradyrhizobium sp. (BR 2003) strains for crotalaria and B. elkanii (BR 2811) for jack bean, supplied by Embrapa Agrobiology, using the methodology suggested by the company.

During cropping, weeds were controlled three times: at 15, 30 and 55 days after emergence, for every treatment, except T2. All the treatments were submitted to sufficient sprinkler irrigation suitable to the crop. The e corn and Fabaceae were harvested manually. The corn was harvested about 150 days after emergence, and each Fabaceae was harvested when approximately $70 \%$ of the pods were dry.

The following evaluations were conducted:

-Final Stand: at harvest, the total of corn and Fabaceae plants were counted in the usable area for subsequent estimation of the plant population.ha ${ }^{-1}$; Ear weight: the usable area of the ears were husked and weighed; Ear diameter: measured in the middle third of all ears with a caliper; Ear length: measured for all the ears using a ruler; Number of ears per plant: the number of ears per usable area was counted; this value was divided by the stands; Average number of pods per plant: 10 plants were harvested randomly from the usable area of each block; Average number of seeds per pod: pods were harvested randomly from three plants per usable area, and the total number of seeds was counted, which, when divided by the number of pods, was the number of seeds per pod; and Seed yield: seeds harvested in each usable area were dried to approximately $12 \%$ moisture and subsequently weighted.

The following seeds evaluations were performed:

-Germination test: the test was conducted with corn and Fabaceae seeds according to the Regulation for Seed Analysis [8]. Four 50-seed replications were used, placed on two sheets of germitest paper and covered with a sheet to form rolls, which were moistened with distilled water 2.5 water: 1 paper weight. The rolls were placed in polyethylene bags to retain the moisture. The BOD germinators were regulated to maintain temperature between $20^{\circ} \mathrm{C}$ and $30^{\circ} \mathrm{C}$ (a 16-hour dark period and an 8-hour light period, respectively). The seedlings were evaluated according to the period determined by the Regulation for Seed Analysis (RAS) for each species and the results obtained were expressed as percentage of normal seedlings;

-Germination speed index (IVG): corn and Fabaceae seeds were evaluated every day during the germination test, from the day of the first radicle issue until the last count as established by the Regulation for Seed Analysis [8] for the germination test. The formula proposed by Maguire (1962) was used for the calculation;

-Cold germination test: performed only on corn seeds. Fifty seeds were distributed on germitest paper moistened with distilled water equivalent to 2.5 times the weight of the paper, with four replications. After seeding, the rolls were 
placed inside plastic bags and maintained inside a BOD incubator set at $10^{\circ} \mathrm{C}$ for seven days. After this period, the rolls inside the plastic bags were transferred to a germinator set at a temperature alternating between 20 and $30^{\circ} \mathrm{C}$, where they remained for seven more days. The germination was evaluated performed according to the recommendations of the Regulation for Seed Analysis [8];

-Seedling emergence in greenhouse: performed on corn and Fabaceae seeds, with four 50 -seed replications sown in individual cells, with Baseplant ${ }^{\oplus}$ substrate, in polystyrene trays placed in a greenhouse. Corn was evaluated until the seventh day, crotalaria until the eighth day, jack bean until the tenth day and velvet bean until the fourteenth day after sowing, considering the emerged seedlings as present and the result in was expressed percentage;

-Emergence rate index (IVE): determined together with the seedling emergence test and conducted on corn and Fabaceae seeds; the count was performed daily from the first seedling day until the seventh for corn, the eighth for crotalaria, the tenth for jack bean and the fourteenth for velvet bean, after sowing [9];

-Electrical conductivity: the Bulk Conductivity method [10] was used on corn and Fabaceae, with four 50-seed replications, which were put in $200 \mathrm{~mL}$ plastic cups with $75 \mathrm{~mL}$ di-ionized water and kept in a BOD germination chamber at $25^{\circ} \mathrm{C}$ for 24 hours. The electrical conductivity was then read in the soaking solution using an electrical conductivity meter (EC meter).

The analysis of variance on data was also carried out, and, for the variables where significant effects occurred $(P<0.05)$, the orthogonal contrast effect was evaluated (Table 2).

The analyses were carried out using the software application SAEG - Statistical Analysis Systems, version 9.0 [11].

\section{Results and Discussion}

Table 3 and Table 4 show, respectively, the estimation of contrasts and the average of each treatment for the final stand, average number of ears, average ear weight, cob diameter, cob length and corn yield.

Comparison of the cropping systems (C1) showed that intercropping interfered positively on the average number of ears per corn plant (Table 3 and Table 4). Researchers evaluated corn monoculture and jack bean intercropping

Table 2. Orthogonal contrasts used for statistical analysis of data.

\begin{tabular}{ll}
\hline Contrast & Comparison \\
\hline C1-Corn in monoculture (T1 + T2 + T3) versus corn in mixed cultivation (T4 + T5); It compares the monoculture with the mixed cultivation \\
$\begin{array}{l}\text { C2-Corn in monoculture with weeding }(\mathrm{T} 1+\mathrm{T} 2) \text { versus corn in monoculture } \\
\text { without weeding (T3); }\end{array}$ & It compares the effect of weeding in monoculture \\
$\begin{array}{l}\text { C3-Corn in monoculture with weeding and complete fertilization (T1) versus corn } \\
\text { in monoculture with weeding but no complete fertilization (T2); }\end{array}$ & It compares the effect of fertilization in the monoculture \\
$\begin{array}{l}\text { C4-Corn in mixed cultivation with crotalaria (T4) corn in mixed cultivation } \\
\text { with jack bean (T5). }\end{array}$ & $\begin{array}{l}\text { It compares the effect of crotalaria and jack bean in mixed } \\
\text { cultivation with corn }\end{array}$ \\
\hline
\end{tabular}


Table 3. Estimation of contrasts, averages per plot, final stand, average number of ears average ear weight, ear diameter ear length and corn yield.

\begin{tabular}{|c|c|c|c|c|c|c|}
\hline Contrasts & $\begin{array}{l}\text { Final stand } \\
\left(\text { plants } \cdot \mathrm{ha}^{-1} \text { ) }\right.\end{array}$ & $\begin{array}{l}\text { Average number of } \\
\text { cobs }\end{array}$ & $\begin{array}{l}\text { Average weight of } \\
\operatorname{cobs}^{\mathrm{ns}}\left(\mathrm{kg} \cdot \mathrm{ha}^{-1}\right)\end{array}$ & $\begin{array}{l}\text { Diameter of } \\
\operatorname{cob}^{\mathrm{ns}}(\mathrm{cm})\end{array}$ & $\begin{array}{l}\text { Length of } \mathrm{cob}^{\mathrm{ns}} \\
\qquad(\mathrm{cm})\end{array}$ & $\begin{array}{l}\text { Productivity }{ }^{\mathrm{ns}} \\
\quad\left(\mathrm{Mg} \cdot \mathrm{ha}^{-1}\right)\end{array}$ \\
\hline$\hat{C} 1$ & $3437^{\text {n.s. }}$ & $-0.18^{\star *}$ & 0.02 & -0.02 & 1.72 & 0.82 \\
\hline$\hat{\mathrm{C}} 2$ & $7500^{\star \star}$ & $0.28^{\star *}$ & 0.01 & -0.21 & 0.86 & 2.09 \\
\hline$\hat{C} 3$ & $-3750^{*}$ & $0.12^{\text {n.s. }}$ & 0.02 & 0.50 & 1.20 & 0.41 \\
\hline$\hat{C} 4$ & $625^{\text {n.s. }}$ & $0.06^{\text {n.s. }}$ & 0.02 & 0.23 & 1.48 & 1.57 \\
\hline C.V (\%) & 5.29 & 10.72 & 22.04 & 16.97 & 14.88 & 31.16 \\
\hline
\end{tabular}

${ }^{*}$ Significant to $5 \%$ probability; ${ }^{* *}$ Significant to $1 \%$ probability; ${ }^{\text {ns }}$ Not significant.

Table 4. Final stand, average number of ears, average ear weight, ear diameter, ear length and corn yield of each treatment.

\begin{tabular}{|c|c|c|c|c|c|c|}
\hline Treatments & $\begin{array}{l}\text { Final stand } \\
\text { (plants } \cdot \mathrm{ha}^{-1} \text { ) }\end{array}$ & $\begin{array}{c}\text { Average } \\
\text { number of cobs }\end{array}$ & $\begin{array}{c}\text { Average weight } \\
\text { of cobs } \\
\left(\mathrm{kg} \cdot \mathrm{ha}^{-1}\right)\end{array}$ & $\begin{array}{c}\text { Diameter of } \\
\operatorname{cob}(\mathrm{cm})\end{array}$ & $\begin{array}{l}\text { Length of cob } \\
\qquad(\mathrm{cm})\end{array}$ & $\begin{array}{c}\text { Productivity } \\
\left(\mathrm{Mg} \cdot \mathrm{ha}^{-1}\right)\end{array}$ \\
\hline Corn + NPK + weeding & 41,250 & 1.16 & 0.11 & 3.92 & 15.88 & 4.37 \\
\hline Corn + weeding & 45,000 & 1.04 & 0.09 & 3.42 & 14.68 & 3.96 \\
\hline Corn + NPK & 35,625 & 0.82 & 0.09 & 3.88 & 14.42 & 2.07 \\
\hline Corn + crotalaria & 37,500 & 1.22 & 0.09 & 3.87 & 14.01 & 3.43 \\
\hline Corn + jack bean & 36,875 & 1.16 & 0.07 & 3.64 & 12.53 & 1.86 \\
\hline
\end{tabular}

and, others evaluated the economic and technical performance of corn intercropped with forages of the Panicum and Brachiaria genera in an integrated crop-livestock system, but did not observe any difference when analyzing the same variable [12] [13].

There was no significant difference between monoculture and intercropping for final stand, average weight, ear diameter and length and corn yield (Table 3).

This corroborates the results of some researchers, who worked with different corn cultivars and Poaceae in intercropping and monoculture and observed no effect for the final stand [14].

It is important to stress that the coefficient of variation was high for yield, which could have interfered the $\mathrm{F}$ test sensitivity to detect the contrast significance (Table 3). In general, field experiments show more variability in results and, consequently, in coefficients of variation.

Weed control had a positive effect on the plant final stand and the average number of ears; in other words, the corn monoculture treatment that did not receive this management obtained lower values compared to the other corn monoculture treatments that were evaluated for this contrast, indicating that the absence of weed control is a negative influence on corn plant final stand (Table 3-C2 and Table 4). Nevertheless, studies on corn intercropped with Brachiaria brizantha, showed that there was no statistical difference between the weed control and non-weed control treatment for corn plant final stand [15]. 
Even though the corn monoculture supplemented with NPK fertilization at seeding presented a final stand lower than 3750 plants.ha ${ }^{-1}$ compared to the corn monoculture without this fertilization (Table 3), the other variables of corn monoculture with fertilization at seeding presented higher absolute numbers in relation to the culture without fertilization at seeding (Table 4). This increase in yield was also observed in corn plants with mineral fertilization and the no-till system [16].

The corn plants intercropped with crotalaria and e corn plants intercropped with jack bean did not present statistical difference in the yield evaluation (Table 3). This similarity in yield values for corn intercropped with Fabaceae was also reported for corn intercropped with Mucuna deeringiana, Cajanus caja, crotalaria and jack bean [17].

However, when only the absolute values were observed, it was verified that the corn yield in intercropping with crotalaria was $84 \%$ higher than corn yield when intercropped with jack bean. This must be considered by the producer, because the price of $1 \mathrm{~kg}$ corn, according to its quotation in the market, is approximately $\$ 0.16$; therefore, the sale of corn intercropped with crotalaria would net approximately $\$ 250.60 /$ ha more than the price obtained for corn intercropped with jack bean.

Table 5 and Table 6 show, respectively, the contrast estimates and the averages for each treatment of germination, speed germination index, emergence, speed emergence index, cold test and electrical conductivity of the corn seeds.

Table 5. Estimates of contrasts, averages per plot, germination, speed germination index, emergence, speed emergence index, cold test and electrical conductivity.

\begin{tabular}{|c|c|c|c|c|c|c|}
\hline Contrasts & $\begin{array}{c}\text { Germination } \\
\%\end{array}$ & IVG & $\begin{array}{c}\text { Emergence }^{\text {n.s. }} \\
\%\end{array}$ & IVE & $\begin{array}{c}\text { Cold Test } \\
\%\end{array}$ & $\begin{array}{c}\text { Electrical condutivy } \\
\mu \mathrm{S} \cdot \mathrm{cm}^{-1} \cdot \mathrm{g}^{-1}\end{array}$ \\
\hline Ĉ 1 & $-0.75^{\text {n.s. }}$ & $-0.28^{\star}$ & 0.26 & $0.23^{\text {n.s. }}$ & $1.42^{\text {n.s. }}$ & $-4.20^{\text {n.s. }}$ \\
\hline$\hat{\mathrm{C}} 2$ & $-1.50^{\text {n.s }}$ & $-0.60^{\star \star}$ & 0.75 & $-0.10^{\text {n.s. }}$ & $-2.00^{\star}$ & $27.35^{\star *}$ \\
\hline$\hat{\mathrm{C}} 3$ & $2.00^{*}$ & $0.13^{\text {n.s. }}$ & -0.50 & $1.35^{*}$ & $4.00^{\text {n.s. }}$ & $-22.10^{*}$ \\
\hline$\hat{\mathrm{C}} 4$ & $-1.50^{\text {n.s. }}$ & $-0.06^{\text {n.s. }}$ & 0.50 & $-1.09^{\text {n.s. }}$ & $-1.50^{\text {n.s. }}$ & $-63.07^{* *}$ \\
\hline C.V (\%) & 1.27 & 1.28 & 1.50 & 5.78 & 2.58 & 10.95 \\
\hline
\end{tabular}

${ }^{\star}$ Significant to $5 \%$ probability; ${ }^{* *}$ Significant to $1 \%$ probability; ${ }^{\mathrm{ns}}$ Not significant.

Table 6. Germination, speed germination index, emergence, speed emergence index, cold test and electrical conductivity of each treatment.

\begin{tabular}{|c|c|c|c|c|c|c|}
\hline Treatments & $\begin{array}{c}\text { Germination } \\
\%\end{array}$ & IVG & $\begin{array}{c}\text { Emergence }^{\text {n.s. }} \\
\%\end{array}$ & IVE & $\begin{array}{c}\text { Cold Test } \\
\%\end{array}$ & $\begin{array}{c}\text { Electrical condutivy } \\
\mu \mathrm{S} \cdot \mathrm{cm}^{-1} \cdot \mathrm{g}^{-1}\end{array}$ \\
\hline Corn + NPK + weeding & 99.00 & 15.90 & 98.50 & 11.91 & 98.50 & 118.48 \\
\hline Corn + weeding & 97.00 & 15.77 & 99.00 & 10.56 & 94.50 & 140.58 \\
\hline Corn + NPK & 99.50 & 16.44 & 98.00 & 11.34 & 98.50 & 102.18 \\
\hline Corn + crotalaria & 98.50 & 16.29 & 99.00 & 10.49 & 95.00 & 93.08 \\
\hline Corn + jack bean & 100.00 & 16.35 & 97.50 & 11.58 & 96.50 & 156.15 \\
\hline
\end{tabular}


The corn seeds from intercropping presented higher GVI than the corn seeds (Table 5-C1). It can be stated that intercropping resulted in greater vigor, even though the germination was similar to monoculture, which corroborates a study that evaluated the influence of different cropping systems on corn seeds, physiological quality and showed that corn intercropped with Cajanus cajan promoted corn seed vigor [18].

Wedd control negatively influenced the GVI, cold test and corn seed electrical conductivity or (Table 5-C2). It must be considered that, although they are statistically different, the vigor of the seeds involved in this contrast was high (Table 6). Researchers verified that the presence of weed roots in the field (cultivation) did not influence corn seed germination and vigor [19].

The seeds from corn in monoculture + NPK presented higher germination values and lower electrical conductivity values (Table $5-\mathrm{C}$ ). This corroborates data in the literature that reported that seeds treated with mineral fertilizer presented lower conductivity because of the greater integrity of their membranes [18].

Although the corn plants intercropped with crotalaria and jack bean were not statistically different in the yield evaluation (Table 3 ), their seeds were different when the electrical conductivity vigor was evaluated (Table 5-C4). This indicates that seeds from intercropping with crotalaria are more vigorous than those intercropped with jack bean. Some researchers, evaluated the physiological quality of soy seeds under no till in relation to plant covering, also observed differences in seed vigor when using this test [20].

Table 7 shows crotalaria and jack bean yield values, both intercropped with corn.

It can be stated for crotalaria seeds that the average number of pods per plant, average number of seeds per pod and yield were very satisfactory. These values were higher than those obtained by researchers [21], who evaluated crotalaria production in monoculture. The values were similar to the average number of seeds (7.3) and productivity (0.94 $\left.\mathrm{Mg} \cdot \mathrm{ha}^{-1}\right)$ reported by Eiras and Coelho [22], who used the same soil as the present study to evaluate different seed densities and pruning effects on Crotalaria juncea seed production in monoculture.

Although not statistically significant, the difference between corn yield $y$ in monoculture and intercropping was $820 \mathrm{~kg}$. Thus, the producer would not earn approximately $\$ 115.66 /$ ha corn intercropping. But the price of $1 \mathrm{~kg}$ crotalaria seeds is approximately $\$ 3.01$, and, in the case of corn intercropped with crotalaria, the producer would earn $\$ 2800.00$ per hectare, while with intercropping

Table 7. Final stand, average number of pods per plant, average number of seeds per pod and yield Fabaceae.

\begin{tabular}{ccccc}
\hline FABACEAE & $\begin{array}{c}\text { Final stand } \\
\left(\text { plant }^{-1} \mathbf{h a}^{-1}\right)\end{array}$ & $\begin{array}{c}\text { Average number of } \\
\text { pods per plant }\end{array}$ & $\begin{array}{c}\text { Average number of } \\
\text { seeds per pod }\end{array}$ & Productivity $\left(\mathrm{Mg}^{-h a^{-1}}\right)$ \\
\hline Crotalaria & 25,833 & 87.3 & 7.2 & 0.93 \\
Jack bean & 45,833 & 1.8 & 8.6 & 1.02 \\
\hline
\end{tabular}


with jack bean the value would be $\$ 3070.00$.

In addition to the economic advantage, intercropping may contribute to increase in yield per unit of area, because production can be diversified in the same area and, consequently, provide better income distribution. Intercropping also promotes more efficient use of labor, an adequate use of the available resources, increased soil protection against erosion and better weed root control than in monoculture.

Table 8 shows the quality of crotalaria and jack bean seeds, both intercropped with corn. The crotalaria seedgermination percentage and IVG were higher than those reported in the literature, when the seeds of this specie were evaluated in monoculture. The electrical conductivity value of the seeds found by these authors $\left(140 \mu \mathrm{S} \cdot \mathrm{cm}^{-1} \cdot \mathrm{g}^{-1}\right)$ was equivalent to the value found in the present study [23].

The Jack bean seed physiological quality presented high germination and emergence values (Table 8), which were higher than observed by researchers evaluating the physiological potential of jack bean seeds [24].

\section{Conclusions}

Intercropping increased the average number of corn ears and the IVG of their seeds.

Weed control positively influenced the final stand and the average number of corn ears, although it negatively influenced the corn seed cold test.

Fertilization with NPK at corn sowing positively influenced the seed electrical conductivity.

The yield of corn plants intercropped with crotalaria and with jack bean was statistically similar, but the absolute figures must be considered for economic purposes.

The corn seeds coming from intercropping with crotalaria had more vigor compared to the corn seeds intercropped with jack bean. Crotalaria and jack bean, when intercropped with corn, presented higher production, germination and vigor.

\section{Acknowledgements}

The authors thank the "Fundação de Apoio e Amparo à Pesquisa do Rio de Janeiro" (FAPERJ) and the "Fundação de Amparo à Pesquisa e ao Desenvolvimento Científico e Tecnológico do Maranhão" (FAPEMA) for the

Table 8. Germination, speed germination index (IVG), emergence, speed emergence index (IVE) and electrical conductivity of Fabaceae seeds.

\begin{tabular}{cccccc}
\hline FABACEAE & $\begin{array}{c}\text { Germination } \\
\%\end{array}$ & IVG & $\begin{array}{c}\text { Emergence } \\
\%\end{array}$ & IVE & $\begin{array}{c}\text { Electrical conductivity } \\
\mu \mathrm{S} \cdot \mathrm{cm}^{-1} \cdot \mathrm{g}^{-1}\end{array}$ \\
\hline Crotalaria & 82.00 & 36.26 & 73.00 & 17.84 & 141.50 \\
Jack bean & 91.25 & 7.2 & 91.25 & 3.68 & 107.45 \\
\hline
\end{tabular}


financial support for the execution of the project and publication of the article, respectively.

\section{References}

[1] Nascimento, J.T., Silva, I.F., Santiago, R.D. and Silva Neto, L.F. (2005) Effect of Legumes on the Physical Attributes and Organic Carbon of an Alfisol. Brazilian Journal of Soil Science, 29, 825-831. http://www.scielo.br/pdf/rbcs/v29n5/27894.pdf

[2] Fontanétti, A., Carvalho, G.J., Gomes, L.A.A., Almeida, K., Moraes, S.R.G. and Teixeira, C.M. (2006) The Use of Green Manure in Crisphead Lettuce and Cabbage Production. Horticultura Brasileira, 24, 146-150. http://www.scielo.br/scielo.php?script=sci_arttext\&pid=S0102-05362006000200004

[3] EMBRAPA-Brazilian Agricultural Research Corporation (2012) Cultivation of Maize-Cultivars. Embrapa Milho e Sorgo.

http://sistemasdeproducao.cnptia.embrapa.br/

[4] Valentini, L., Oliveira, L.A.A. and Ferreira, J.M. (2008) Corn Seed Production Variety for Own Use in Hydrographic Basin Properties. Rio Rural Program, Niterói, $14 \mathrm{p}$.

[5] EMBRAPA-Brazilian Agricultural Research Corporation (2006) Brazilian System of Soil Classification. Embrapa Solos, Rio de Janeiro, $306 \mathrm{p}$.

[6] EMBRAPA-Brazilian Agricultural Research Corporation (1997) Manual Methods of Soil Analysis. 2nd Edition, CNPS-Ministry of Agriculture and Supply, Rio de Janeiro, $212 \mathrm{p}$.

[7] De-Polli, H., et al. (1988) Manual of Fertilization for the State of Rio de Janeiro. 2nd Edition, Editora Rural Univercity, Rio de Janeiro, 179 p.

[8] BRASIL. Ministry of Agriculture, Livestock and Supply (2009) Rules for Seed Analysis. Ministry of Agriculture, Livestock and Supply. Secretariat of Agricultural Defense. MAPA/ACS, Brasília, 395 p.

[9] Maguire, J.D. (1962) Speed of Germination-Aid in Selection and Evaluation for Seedling Emergence and Vigor. Crop Science, 2, 176-177.

https://dl.sciencesocieties.org/publications/cs/abstracts/2/2/CS0020020176 https://doi.org/10.2135/cropsci1962.0011183X000200020033x

[10] Vieira, R.D. and Carvalho, M.N. (1994) Seed Vigor Tests. FUNEP, Jabuticabal, 164 p.

[11] Ribeiro Júnior, J.I. (2007) Statistical Analyzes in SAEG. UFV, Viçosa, 301 p.

[12] Oliveira, T.K., Carvalho, G.J., Moraes, R.N.S. and Magalhães Júnior, P.R. (2003) Agronomic Characteristics and Phytomass of Corn in Isolated and Associated Cultivation with Leguminous Plants. Science and Agrotechnology, Lavras, 27, 223-227. http://www.scielo.br/pdf/cagro/v27n1/a29v27n1.pdf

[13] Pariz, C.M., Andreotti, M., Tarsitano, M.A.A., Bergamaschine, A.F., Buzetti, S. and Chioderoli, C.A. (2009) Technical and Economic Performance of Corn Intercropped with Panicum and Brachiaria Forage in Crop-Livestock Integration System. Tropical Agriculture Research, 39, 360-370. http://www.revistas.ufg.br/index.php/pat/article/view/5651

[14] Jakelaitis, A., Daniel, T.A.D., Alexandrino, E., Simões, L.P., Souza, K.V. and Ludtke, J. (2010) Maize and Forage Grass Cultivars under Monocropping and Intercropping Systems. Tropical Agriculture Research, 40, 380-387. http://www.revistas.ufg.br/index.php/pat/article/view/5924/8123

[15] Jakelaitis, A., Santos, J.B., Vivian, R. and Silva, A.A. (2007) Microbial Activity and Production of Corn (Zea mays) and Brachiaria brizantha under Different Methods 
of Weed Control. Weed, 25, 71-78.

http://www.scielo.br/scielo.php?pid=S0100-83582007000100008\&script=sci_arttext

[16] Carvalho, M.A.C., Soratto, R.P., Athayde, M.L.F., Arf, O. and Sá, M.E. (2004) Yield of Corn Grown after Green Manures under No-Tillage and Conventional Management System. Brazilian Agricultural Research, 39, 47-53.

http://www.scielo.br/scielo.php?script=sci_arttext\&pid=S0100-204X2004000100007

[17] Heinrichs, R., Vitti, G.C., Moreira, A., Figueiredo, P.A.M., Fancelli, L.A. and Corazza, E.J. (2005) Soil Chemical Characteristics and Green Manureyield in a Corn Intercropped System. Brazilian Journal of Soil Science, 29, 71-79.

http://www.scielo.br/scielo.php?pid=S0100-06832005000100008\&script=sci_abstrac $\underline{\mathrm{t} \& \mathrm{t} \operatorname{lng} \mathrm{p}=\mathrm{pt}}$

[18] Nunes, H.V., Silva, I.F., Bruno, R.L.A., Barros, D.I. and Pereira, W.E. (2006) Culture Systems, Velvet Bean and Mineral Fertilization Influence on Maize Seeds Physiological Quality. Journal of Seed Science, 28, 6-12.

http://www.scielo.br/scielo.php?pid=S0101-31222006000300002\&script=sci_arttext

[19] Silva, P.C.L., Silva, K.M.B., Miranda, G.V., Ribeiro, M.C.C. and Grangeiro, L.C. (2006) Influence of Weeds on Morphological and Physiological Characteristics of Corn Seeds. Brazilian Journal of Corn and Sorghum, 5, 232-240. http://rbms.cnpms.embrapa.br/index.php/ojs/article/viewArticle/186

[20] Lima, E.V., Crusciol, C.A.C., Cavariani, C. and Nakagawa, J. (2009) Agronomic Traits, Yield and Physiological Quality of "Safrinha" (Off-Season) Soybean under No Till as a Function of Plant Cover and Surface Liming. Journal of Seed Science, 31, 69-80. http://www.scielo.br/pdf/rbs/v31n1/a08v31n1.pdf

[21] Kappes, C., Arf, O., Arf, M.V., Gitti, D.C. and Alcalde, A.M. (2011) Use of Growth Regulators in Crotalaria Juncea L. Growth and Yield. Tropical Agriculture Research, 41, 508-518. http://www.revistas.ufg.br/index.php/pat/article/view/10768

[22] Eiras, P.P. and Coelho, F.C. (2012) Evaluation of Different Plant Densities and Pruning in Seed Yield of Crotalaria juncea L. Ceres Magazine, 59, 668-676. http://www.scielo.br/scielo.php?pid=S0034-737X2012000500012\&script=sci_abstra ct\&tlng=pt

[23] Kappes, C., Arf, O., Sá, M.E., Ferreira, J.P., Portugal, J.R., Alcalde, A.M. and Vilela, R.G. (2012) Growth Regulators and Its Effect on the Physiological Quality of Seeds and Growth Seedlings of Sunn Hemp. Bioscience Journal, 28, 180-190. http://www.seer.ufu.br/index.php/biosciencejournal/article/view/11639

[24] Feiden, A., Jorge, M.H.A., Arruda, E.S., Lucas, D.C. and Almeida, W.B. (2011) Alternate Test for the Evaluation of the Physiological Potential of Corn and Bean Seeds. Press Release 89, Embrapa Pantanal.

http://www.cpap.embrapa.br/publicacoes/online/COT89.pdf 